\title{
PENGARUH BUDAYA SIRI' DALAM KASUS PENYALAHGUNAAN SENJATA TAJAM DI KABUPATEN SINJAI
}

\author{
Jusri Mudjrimin', A. Adry Ismawan Putra ${ }^{2}$ \\ ${ }^{1}$ Institut Agama Islam Muhammadiyah Sinjai, Jl.Sultan Hasanuddin No.20, Kabupaten Sinjai \\ ${ }^{2}$ Institut Agama Islam Muhammadiyah Sinjai, Jl.Sultan Hasanuddin No.20, Kabupaten Sinjai \\ E-mail:jusri_m@yahoo.co.id, Tlp:+6285255697732
}

\begin{abstract}
Abstrak
Penelitian ini bertujuan untuk mengetahui dan menganalisis Faktor-faktor yang berpengaruh dalam budaya siri" sehingga terjadi Penyalahgunaan Senjata Tajam di Kabupaten Sinjai dan Untuk mengetahui dan menganalisis Tindakan yang dilakukan dalam upaya penyelesaian Kasus Penyalahgunaan Senjata Tajam di Kabupaten Sinjai. Untuk dapat menganalisis peraturan perundang-undangan dan menganalisis pola kehidupan dan perilaku masyarakat berkaitan dengan hukum yang terkait dalam interaksi dimasyarakat maka penelitian ini menggunakan metode Pendekatan Empiris. Adapun hasil penelitian menyimpulkan Penyebab terjadinya Penyalahgunaan Senjata Tajam di Kabupaten Sinjai sebagai akibat dari didikan kebudayaan masa lalu, yaitu dijadikannya senjata Tajam sebagai alat untuk menjaga atau untuk membela diri, sikap dan sifat jahat seseorang dapat dipengaruhi oleh sikap dan sifat jahat individu lainnya serta rasa dendam yang timbul akibat malu setelah mendengar ucapan orang lain sehingga nekat mempersiapkan diri dalam melakukan suatu tindak kejahatan menggunakan senjata tajam. Rekomendasi penelitian agar kiranya dilakukannya upaya penyuluhan hendaknya juga melibatkan semua unsur termasuk pemuka agama dan tokoh-tokoh desa, Masyarakat hendaknya mendukung dan aktif dalam melaporkan segala tindak kejahatan serta Aparat Kepolisian hendaknya lebih tegas dalam menerapkan hukum terhadap pelaku kejahatan sehingga tidak membuat resah dimasyarakat.
\end{abstract}

Kata Kunci: Budaya Siri', Senjata Tajam, Perselisihan.

\begin{abstract}
This study aims to identify and analyze the influencing factors in the siri culture, resulting in the Abuse of Sharp Weapons in Sinjai Regency and to find out and analyze the actions taken in resolving the Sharp Weapons Abuse Case in Sinjai Regency. To be able to analyze statutory regulations and analyze the patterns of life and behavior of the community in relation to laws related to social interactions, this research uses the Empirical Approach method. The results of the research conclude that the cause of the occurrence of sharp weapons abuse in Sinjai Regency is a result of past cultural education, namely the use of sharp weapons as a tool to protect or to defend oneself, a person's evil attitudes and traits can be influenced by the evil attitudes and traits of other individuals and feelings of revenge. which arises as a result of shame after hearing what others say so that they are desperate to prepare themselves to commit a crime using a sharp weapon. Research recommendations so that counseling efforts should also involve all elements including religious and village leaders, the community should support and be active in reporting all crimes and the police should be more assertive in implementing the law against criminals so as not to upset the community.
\end{abstract}

Keywords: Siri Culture', Sharp Weapons, Discord. 


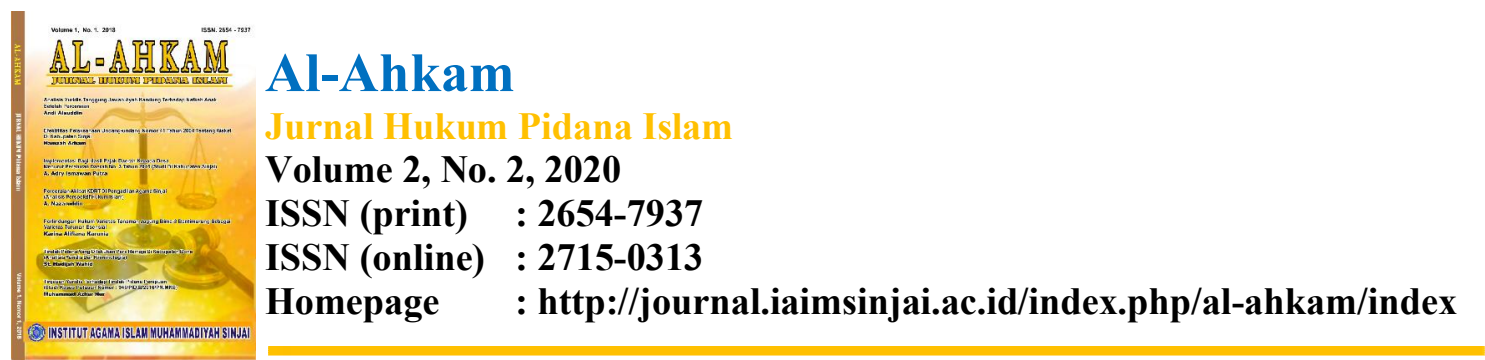

\section{Pendahuluan}

Masyarakat adalah orang yang hidup bersama yang menghasilkan kebudayaan. Dengan demikan tidak ada masyarakat yang tidak mempunyai kebudayaan dan sebaliknya tidak ada kebudayaan tanpa masyarakat sebagai wadah dan pendukungnya.

Perilaku kesopanan sangat erat kaitannya dengan budaya dan bahasa suatu etnik. Bahasa merupakan cerminan budaya. Sebaliknya, budaya adalah nilai, prinsip yang dapat diyakini kebenarannya dalam suatu masyarakat penutur suatu bahasa, dan dapat dijadikan panduan dalam berinteraksi dan berkomunikasi, termasuk budaya masyarakat Bugis di Kabupaten Sinjai Provinsi Sulawesi Selatan.

Sama seperti etnis-etnis lainnya, budaya masyarakat Bugis di Kabupaten Sinjai Provinsi Sulawesi Selatan juga mengenal norma dan aturan adat yang disebut Pangadarreng. Dalam Pangadarreng tersebut terdapat Konsep Siri' atau keadaan tertimpa malu atau terhina. Dalam konteks pengasuhan, orang bugis dimanapun selalu menegakkan budaya Siri' agar tidak tertimpa rasa malu dan terhina akibat dari perbuatannya.

Nilai Siri' sebagai nilai utama harus dipandang sebagai nilai-nilai yang utuh dan mempunyai dua sisi, ibarat mata uang harganya terletak pada dua sisinya. Satu darinya hilang tidak berhargalah ia. Nilai yaitu sesuatu yang dianggap berharga. Sama halnya dengan senjata tradisional Suku Bugis yang dikenal dengan Badik/Kawali. Badik merupakan benda yang mempunyai makna tersendiri bagi masyarakat Suku Bugis yang mempercayainya.

Badik/Kawali merupakan salah satu senjata tradisional yang menjadi identitas budaya suku-suku bangsa di bumi Melayu, termasuk sebagai senjata khas orang-orang Bugis. Bagi masyarakat Suku Bugis asli, memiliki Badik merupakan suatu keharusan, seperti ungkapan dalam bahasa Bugis yang berbunyi "Tania ugi narekko de'napunnangi kawali" artinya yaitu "bukan seorang Bugis jika tidak memiliki Badik".

Badik/kawali adalah fenomena yang menarik, karena kebiasaan yang mengakar cukup kuat namun disisi lain dilihat dari hukum nasional bangsa Indonesia yang melarang kebiasaan tersebut menjadi permasalahan yang kontroversial pada masyarakat Suku Bugis.

Dalam hukum nasional kita kebiasaan membawa badik/kawali tersebut merupakan hal yang dilarang karena alat alat-alat atau benda yang dibuat untuk kegunaan menyerang pihak lain oleh penggunanya, inilah yang disebut sebagai senjata. Entah itu menyerang sebagai upaya membela diri atau untuk melumpuhkan dan membunuh. Menurut UU darurat No. 12 Tahun 1951 tentang mengubah "Ordonnantietijdelijke Bijzondere Strafbepalingen" dalam Pasal 2 ayat (1) dan (2). Dalam pasal ini pelaku diancam dengan hukuman penjara selama-lamanya sepuluh tahun.

Untuk mencegah dan memberantas terjadinya pelanggaran yang akan dijatuhi hukuman atau pidana seyogyanya dibutuhkan berbagai upaya untuk ditempuh. Ditempuhnya upaya hukum untuk menjerat para pelaku suatu pelanggaran yang dikategorikan sebagai tindak pidana dalam Kitab Undang-Undang Hukum Pidana Indonesia, diharapkan mampu untuk memberikan efek jera sehingga tidak mengulangi kembali perbuatannya tersebut dan kembali untuk menjadi orang baik yang dapat terima dimasyarakat.

Setiap tindakan kekerasan yang melibatkan senjata tajam seringkali dikaitkan dengan sikap individu yang berakar dari norma kedaerahan setiap kebudayaan yang memiliki peran dominan dalam kehidupan bermasyarakat untuk mempertahankan diri.

Meningkatnya tindakan kejahatan yang cenderung menggunakan senjata tajam mendorong pemerintah mengeluarkan Undang-Undang Darurat No. 12 Tahun 1951 sebagai tindakan preventif dalam mencegah atau mengurangi tindak kejahatan menggunakan senjata tajam. Selain senjata tajam dalam Undang-Undang Darurat No. 12 Tahun 1951 ini juga mengatur senjata api dan bahan peledak. 


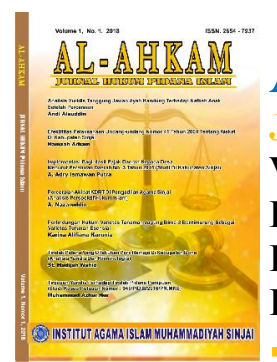

Al-Ahkam

Jurnal Hukum Pidana Islam

Volume 2, No. 2, 2020

ISSN (print) : 2654-7937

ISSN (online) : 2715-0313

Homepage : http://journal.iaimsinjai.ac.id/index.php/al-ahkam/index

Dalam perkembangannya hukum harus mengikuti tuntutan zaman dimana dalam membuat atau merevisi suatu aturan Perundang-Undangan yang baik di dalam masyarakat bukan merupakan pekerjaan yang mudah, hal ini membutuhkan waktu dan tenaga sehingga untuk mencapainya dibutuhkan orang-orang yang memiliki itikat baik, bermoral dan memiliki semangat untuk melahirkan produk Perundang-Undangan yang baik pula yang merupakan kunci untuk mencapai kesuksesan yang diharapkan bersama.

Suatu tindak kejahatan yang telah dilakukan cenderung mengakibatkan suatu kesengsaraan, penderitaan dan nestapa yang akan dialami masyarakat baik secara individu ataupun secara luas. Terjadinya kejahatan bukan hanya terjadi didaerah-daerah atau negaranegara yang tertinggal namun cenderung terjadi didaerah-daerah atau negara-negara yang maju sebagai akibat dari perkembangan kejahatan itu sendiri, baik terhadap nyawa maupun pada tubuh manusia itu sendiri seperti melakukan penganiayaan, mengancam, bahkan melakukan pembunuhan cenderung menggunakan senjata tajam dalam aksinya menimbulkan korban luka bahkan kematian.

Dalam tindakan Preventif ini, pemerintah telah melakukan suatu upaya untuk mengatasi penyalahgunaan senjata tajam sehingga mampu menjadi acuan dalam melakukan pengawasan terhadap kepemilikan senjata tajam secara Illegal. Dari uraian latar belakang masalah tersebut, penulis ingin mengambil suatu penelitian karya ilmiah dengan judul "Pengaruh Budaya Siri’ Dalam Kasus Penyalahgunaan Senjata Tajam Di Kabupaten Sinjai".

\section{Metode}

Dalam penelitian ini peneliti menggunakan metode pendekatan Yuridis Empiris, yang dilaksanakan pada tahun 2020 berlokasi di kabupaten Sinjai Provinsi Sulawesi Selatan, dengan sasaran Penyalahgunaan Senjata Tajam dan subjek penelitian yaitu budaya Siri di Kabupaten Sinjai. Adapun teknik pengumpulan data yang digunakan yaitu penelitian kepustakaan dan teknik interview atau wawancara. Teknik analisa data digunakan yaitu Setelah semua data terkumpul, dalam penulisan data yang diperoleh baik data primer maupun data sekunder maka data-data yang telah diperoleh baik hasil wawancara, dokumentasi, maupun data pustaka dikumpulkan secara utuh kemudian diolah dan dianalisis secara deskriftif kualitatif dengan menggunakan pendekatan undang-undang dan pendekatan kasus serta menafsirkan data berdasarkan teori sekaligus menjawab permasalahan dalam penulisan atau penelitian ini.

\section{Hasil dan Pembahasan}

\subsection{Faktor-faktor yang berpengaruh dalam budaya siri" sehingga terjadi Penyalahgunaan Senjata Tajam di Kabupaten Sinjai.}

Terjadinya suatu perselisihan baik itu antara individu maupun kelompok kerap kali terjadi di kabupaten sinjai, dimana hal ini terkadang dilatar belakangi oleh adanya keinginan untuk menegakkan konsep Siri atau suatu keadaan tertimpa malu atau terhina dalam norma dan aturan adat yang disebut Pangadarreng.

Didikan moral siri' telah ditanamkan sejak usia dini kedalam pola hidup dimasyarakat oleh leluhur suku Bugis. Keadaan seperti ini baik secara langsung maupun tidak langsung akan membawa dampak yang berpengaruh dalam kehidupan masyarakat, yaitu semakin merosotnya nilai sakral dalam budaya hubungan manusia dengan manusia yang lain khususnya dalam penyelesaian perselisihan di kalangan suku Bugis. Nilai-nilai hubungan antar sesama masyarakat suku bugis maupun dengan suku atau kebudayaan lainnya menjadi sulit untuk beradaptasi karna masyarakat masih menjunjung tinggi budaya masa lalu. 


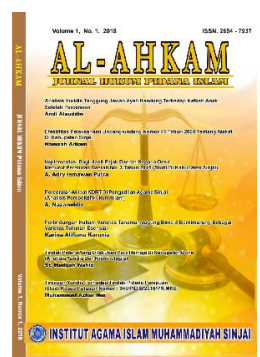

Volume 2, No. 2, 2020

ISSN (print) : 2654-7937

ISSN (online) : 2715-0313

Homepage : http://journal.iaimsinjai.ac.id/index.php/al-ahkam/index

Kasus Penyalahgunaan Senjata Tajam bisa saja terjadi karna spontanitas, sehingga menimbulkan korban yang tidak terduga atau karna kondisi dan situasi setempat yang memberi kemungkinan untuk berbuat. Penyalahgunaan Senjata Tajam dapat pula terjadi karena memang sebelumnya telah direncanakan.

Terkait kasus Penyalahgunaan Senjata Tajam yang terjadi di Kabupaten Sinjai Provinsi Sulawesi Salatan berikut data yang di peroleh :

1. Data Kepolisian Resort Sinjai

Kasus Penyalahgunaan Senjata Tajam di Kabupaten Sinjai yang terjadi, dapat di gambarkan dalam bentuk tabel yang selama kurun waktu 5 (Lima) tahun terakhir yaitu antara tahun 2015 hingga tahun 2019 pada tabel 1

Tabel 1.

Kasus Penyalahgunaan Senjata Tajam Di Kepolisian Resort Sinjai

Tahun 2015-2019

\begin{tabular}{|c|c|c|c|}
\hline Tahun & $\begin{array}{c}\text { Perkara yang } \\
\text { dilaporkan }\end{array}$ & $\begin{array}{c}\text { Perkara yang } \\
\text { dilimpahkan }\end{array}$ & $\begin{array}{c}\text { Perkara yang tidak } \\
\text { dilimpahkan }\end{array}$ \\
\hline 2015 & 9 & 5 & 4 \\
2016 & 16 & 5 & 11 \\
2017 & 2 & - & 2 \\
2018 & 2 & 2 & - \\
2019 & 2 & 1 & 1 \\
\hline Jumlah & $\mathbf{3 1}$ & $\mathbf{1 3}$ & $\mathbf{1 8}$ \\
\hline
\end{tabular}

Sumber Data : Polres Sinjai Tahun 2020

Berdasarkan data yang diperoleh dari tabel 1 diatas menunjukkan bahwa dalam kurun waktu 5 (Lima) tahun terakhir yaitu antara tahun 2015 hingga tahun 2019 telah terjadi kasus Penyalahgunaan Senjata Tajam di Kabupaten Sinjai sebanyak 31 Kasus yang dilaporkan ke Kepolisian Resort Sinjai, yaitu pada tahun 2015 terjadi 9 Kasus, pada tahun 2016 meningkat menjadi 16 kasus, pada tahun 2017 mengalami penurunan sebanyak 2 kasus, pada tahun 2018 terjadi 2 kasus, pada tahun 2019 terjadi 2 kasus.

Dari data tabel 1 tersebut diatas dapat dilihat bahwa tidak semua perkara yang dilaporkan berhasil dilakukan pelimpahan ke Kejaksaan Negeri Sinjai. Perkara yang berhasil dilimpahkan pada tahun 2015 ada 5 kasus, pada tahun 2016 ada 5 kasus, pada tahun 2017 tidak ada kasus yang dillimpahkan, pada tahun 2018 ada 2 kasus, pada tahun 2019 ada 1 kasus.

Setelah dilakukannya wawancara terhadap penyidik kepolisian resort Sinjai, diperoleh pernyataan tentang mengapa tidak semua perkara yang dilaporkan dilakukan pelimpahan.

"Bahwa Pelaku dan korban sepakat melakukan perdamaian karna adanya hubungan kekerabatan serta adapula kasus yang tidak dilanjutkan karena penyidik tidak memperoleh cukup bukti."

2. Data Kantor Kejaksaan Negeri Sinjai

Penulis memperoleh data Delik penyalahgunaan senjata tajam dari Kejaksaan Negeri Kabupaten Sinjai pada tabel 2 sebagai berikut : 


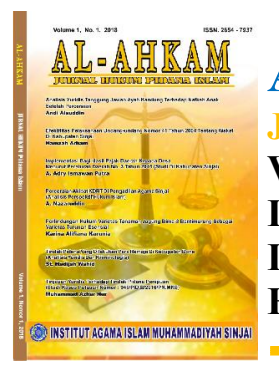

Volume 2, No. 2, 2020

ISSN (print) : 2654-7937

ISSN (online) : 2715-0313

Homepage : http://journal.iaimsinjai.ac.id/index.php/al-ahkam/index

Tabel 2

Delik Penyalahgunaan Senjata Tajam yang ditangani

Kejaksaan Negeri Kabupaten Sinjai Tahun 2015-2019

\begin{tabular}{|c|c|c|l|}
\hline Tahun & $\begin{array}{c}\text { Perkara yang } \\
\text { diterima dari } \\
\text { Kepolisian }\end{array}$ & $\begin{array}{c}\text { Perkara yang } \\
\text { dilimpahkan ke } \\
\text { Pengadilan }\end{array}$ & \multicolumn{1}{|c|}{ Keterangan } \\
\hline 2015 & 5 & 5 & Keseluruhan kasus \\
2016 & 5 & 5 & yang diterima dari \\
2017 & - & - & kepolisian \\
2018 & 2 & 2 & dilimpahkan ke \\
2019 & 1 & 1 & Pengadilan Negeri \\
\cline { 1 - 3 } Jumlah & $\mathbf{1 3}$ & $\mathbf{1 3}$ & Sinjai \\
\hline
\end{tabular}

Pada Tabel 2 tersebut diatas menerangkan bahwa kasus Penyalahgunaan Senjata Tajam di Kabupaten Sinjai yang berlansung sejak tahun 2015 sampai pada tahun 2019 yang di terima oleh Kantor Kejaksaan Negeri Kabupaten Sinjai yang diuraikan sebagai berikut : pada tahun 2015 terjadi sebanyak 5 kasus, pada tahun 2016 terjadi sebanyak 5 kasus, pada tahun 2017 tidak ada kasus, pada tahun 2018 terjadi sebanyak 2 kasus, pada tahun 2019 terjadi sebanyak 1 kasus. Dari keseluruhan kasus yang dianggap telah lengkap dan telah memenuhi syarat maka Kejaksaan Negeri Kabupaten Sinjai melakukan proses pelimpahan perkara ke Pengadilan Negeri Sinjai.

3. Data Pengadilan Negeri Kabupaten Sinjai

Dalam melaksanakan tugasnya, pengadilan diwajibkan melakukan pemeriksaan terhadap semua materi serta segala syarat-syarat formal yang harus dipenuhi yang kemudian dilakukan penentuan jadwal persidangan oleh Majelis Hakim.

Adapun Delik Penyalahguaan Senjata Tajam sejak tahun 2015 sampai pada tahun 2019 yang disidangkan oleh Pengadilan Negeri Kabupaten Sinjai yaitu sebagai berikut :

Tabel 3

Delik Penyalahgunaan Senjata Tajam yang ditangani

Pengadilan Negeri Kabupaten Sinjai Tahun 2015-2019

\begin{tabular}{|c|c|c|l|}
\hline Tahun & $\begin{array}{c}\text { Perkara yang } \\
\text { diterima dari } \\
\text { Kejaksaan }\end{array}$ & $\begin{array}{c}\text { Perkara yang } \\
\text { ditangani } \\
\text { Pengadilan }\end{array}$ & \multicolumn{1}{|c|}{ Keterangan } \\
\hline 2015 & 5 & 5 & Keseluruhan kasus \\
2016 & 5 & 5 & yang diterima dari \\
2017 & - & - & kejaksaan Sinjai \\
2018 & 2 & 2 & disidangkan di \\
2019 & 1 & 1 & Pengadilan Negeri \\
\hline Jumlah & $\mathbf{1 3}$ & $\mathbf{1 3}$ & Sinjai. \\
\hline
\end{tabular}

(Sumber Data : Pengadilan Negeri Kabupaten Sinjai Tahun 2020)

Tabel 3 tersebut diatas menunjukkan secara keseluruhan kasus penyalahgunaan senjata tajam dikabupaten Sinjai yang berlansung sejak tahun 2015 hingga tahun 2019 yang diterima dari kejaksaan Negeri Kabupaten Sinjai. Adapun rincian kasusnya sebagai berikut : pada tahun 2015 terjadi sebanyak 5 kasus, pada tahun 2016 terjadi sebanyak 5 kasus, pada tahun 2017 tidak ada kasus, pada tahun 2018 terjadi sebanyak 2 kasus, pada tahun 2019 


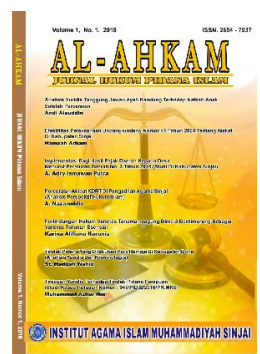

Al-Ahkam

Jurnall Hukum Pidana Islam

Volume 2, No. 2, 2020

ISSN (print) : 2654-7937

ISSN (online) : 2715-0313

Homepage : http://journal.iaimsinjai.ac.id/index.php/al-ahkam/index

terjadi sebanyak 1 kasus. Keseluruhan kasus yang diterima dari kejaksaan Sinjai diproses dan disidangkan di Pengadilan Negeri Sinjai.

Kasus Penyalahgunaan Senjata Tajam yang terjadi di kabupaten Sinjai sedikit berbeda dengan kasus Penyalahgunaan Senjata Tajam yang terjadi di kabupaten/Kota lainnya di Indonesia, hal ini dikarenakan oleh faktor budaya Siri' yang masih ditanamkan oleh orang tua kepada anak-anak suku bugis Sinjai.

Adapun Faktor-faktor yang berpengaruh dalam budaya siri" sehingga terjadi Penyalahgunaan Senjata Tajam di Kabupaten Sinjai yaitu diperoleh data dari keterangan pelaku dan dari keluarga korban yang mengetahui kejadian.

Bahwa hasil pengamatan dan wawancara terhadap beberapa pelaku yang dapat ditemui Rumah Tahanan dan Lembaga Pemasyarakatan Kabupaten Sinjai diperoleh data bahwa faktor penyebab atau hal yang mempengaruhi terjadinya Penyalahgunaan Senjata Tajam di Kabupaten Sinjai terdiri dari beberapa faktor. Hasil dari wawancara yang dilakukan terhadap beberapa pelaku Penyalahgunaan Senjata Tajam tersebut akan dijelaskan dan diteliti serta dilakukan pengkajian lebih lanjut.

1. Faktor Lingkungan Keluarga

Dalam lingkungan keluarga, anak dan anggota keluarga lainnya memiliki peran masing-masing yaitu sebagai makhluk social yang hidup dalam norma-norma tertentu yang salah satunya yaitu Siri' yang dikenal dalam suku Bugis. Norma-norma tersebut diperoleh dari pengalaman anggota keluarga lainnya yang kemudian di terapkan dalam tingkah laku kehidupan anggota keluarga.Pengaruh psikologi dalam lingkungan keluarga berpengaruh terhadap Perilaku seorang anak. Kepribadian baik dan buruk seorang anak tergantung bagaimana lingkungan keluarga berperan aktif dalam mendidik hingga anak memiliki sikap dan kepribadian hingga dewasa nanti.Dalam kasus Penyalahgunaan Senjata Tajam yang dilakukan oleh Ibrahim Alias Lomo Bin Maddu (44 Tahun) yang Ketika diwawancarai mengatakan bahwa mereka melakukan kejahatan Penyalahgunaan Senjata Tajam karena dalam lingkungan keluarga membawa senjata tajam kemana pun mereka pergi di anggap sebagai alat untuk mejaga atau untuk membela diri (Menegakkan Siri'). Ibrahim Alias Lomo Bin Maddu (44 Tahun). mengungkapkan bahwa membawa senjata tajam tersebut didalam keluarganya baik itu Ketika kesawah, berkebun maupun ke acara lainnya tidak mendapat pertentangan dari keluarga atau merupakan hal yang biasa/diperbolehkan. Sehingga dirinya ditangkap dengan tuduhan Melakukan Penganiayaan yang mengakibatkan mati sebagaimana diatur dan diancam pidana dalam Pasal 351 Ayat (3) KUHPidana.Hal ini bermula Ketika keduanya bertemu dan minum minuman keras jenis ballo' (arak) yang kemudian terjadi pembicaraan yang mengusik keluarga ILYAS Bin BEDDU yang kemudian merasa tersinggung dan mendatangi Ibrahim Alias Lomo Bin Maddu di tengah kebun cengkeh kemudian dari arah belakang Terdakwa langsung memarangi Terdakwa sebanyak satu kali dengan menggunakan parang panjang yang mengenai bagian punggung sebelah kiri spontan Terdakwa langsung menoleh dan balik kebelakang dan melihat Korban sambil menyalakan lampu senter dan Saksi USMAN Alias SEMMANG berdiri disamping Korban kemudian Terdakwa berkata dalam bahasa bugis "magai muhettaka amure" yang artinya kenapa memarangi saya paman sehingga Korban menjawab dengan perkataan "muruntunni eppona basyo paruntu" yang artinya sekarang kamu bertemu cucunya basyo paruntu sambil mengarahkan lampu senternya ke mata Terdakwa sehingga Terdakwa berusaha menghalangi cahaya lampu senter sambil mengangkat tangan kiri yang sedang memegang HP.

Pada saat itu Korban memarangi Terdakwa yang kedua kalinya sebanyak satu kali yang mengenai lengan kiri Terdakwa tepat mengenai diatas siku kemudian pada saat itu juga Terdakwa langsung mencabut badik yang terselip dipinggang kiri dengan menggunakan tangan kanan dan menusuk Korban sebanyak satu kali yang mengenai bagian rusuk sebelah 


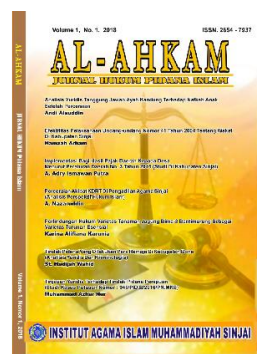

Al-Ahkam

Jurnall Hukum Pidana Islam

Volume 2, No. 2, 2020

ISSN (print) : 2654-7937

ISSN (online) : 2715-0313

Homepage : http://journal.iaimsinjai.ac.id/index.php/al-ahkam/index

kiri dibawah ketiak kemudian Korban memarangi Terdakwa yang ketiga kalinya yang mengenai rusuk sebelah kiri dibawah ketiak sebanyak satu kali kemudian Terdakwa menikam Korban yang kedua kalinya yang mengenai dada (uluhati) dan Korban Bin BEDDU masih sempat memarangi Terdakwa pada bagian pipih dibawah mata sebanyak satu kali dan pada saat itu badik milik Terdakwa tidak bisa tercabut didada (ulu hati) Korban sehingga Terdakwa dengan menggunakan kaki kanan menendang Korban sambil menarik badik yang tertancap didada (ulu hati) Korban sehingga Korban terjatuh dan badik tercabut dibadan Korban kemudian Korban langsung duduk bersila ditanah sandar dipohon cengkeh dan parang yang dipegang sempat mengenai/mengiris pangkal paha Terdakwa sebelah kiri (bagian dalam) dan pada saat itu dalam keadaan ketakutan Saksi USMAN Alias SEMMANG langsung lari pulang ke rumahnya kemudian Terdakwa memegang rambut Korban dengan maksud akan menggorok lehernya namun Korban berkata " $k u$ 'ni ro' yang artinya sudah cukup lalu Terdakwa menjawab dalam bahasa bugis "muissemui fale, magai muhettaka" yang artinya kamu tahu kenapa kamu memarangi saya, sambil Terdakwa memperlihatkan luka kepada Korban kemudian Terdakwa pulang kerumahnya yang berjarak sekitar 200 (dua ratus) meter dari tempat kejadian (hasil wawancara, 14 April 2020)

2. Faktor Pergaulan

Kejahatan Penyalahgunaan Senjata Tajam dikabupaten Sinjai juga dipengaruhi oleh faktor pergaulan. Hal ini dapat kita lihat dari sikap dan sifat jahat seseorang dapat dipengaruhi oleh sikap dan sifat jahat individu lainnya. Namun jika sikap dan sifat jahat seseorang berada ditengah-tengah lingkungan senantiasa mengawasi tingkah laku individu jahat tersebut maka tidak akan terwujud dalam suatu perbuatan jahat karena tidak mengalami perkembangan dan tidak adanya kesempatan untuk melakukan tindak kejahatan.

Dari pernyataan tersebut diatas dapat disimpulkan bahwwa Sifat jahat yang diturunkan oleh orang lain dari pengaruh pergaulan memiliki peran yang cukup besar dalam kasus Penyalahgunaan Senjata Tajam.

Hal ini berkaitan dengan kasus yang menimpa Asdar Alias Adda bin Muhammad Jafar (43 tahun) yaitu membawa senjata tajam telah dimulai sejak dulu karena hampir semua teman sepergaulannya memiliki kebiasaan menyelipkan sebilah badik di pinggang sebelum keluar rumah yang hingga pada akhirnya ditangkap oleh aparat kepoisian karena kepemilikan senjata tajam tanpa ijin.

Kebiasaan menyelipkan sebilah badik di pinggang sebelum keluar rumah merupakan suatu perbuatan yang diperoleh dari sikap dan sifat jahat yang diturunkan oleh teman sepergaulan memiliki peran cukup besar terhadap orang lain (hasil wawancara, 20 April 2020).

3. Faktor Ekonomi

Pada umumnya kejahatan timbul karna adanya faktor ekonomi dan sarana untuk melakukan perbuatan, ketika seseorang timbul rasa untuk ingin memiliki barang atau uang maka seseorang akan memiliki kecenderungan untuk mempersiapkan diri dalam melakukan suatu tindakan sehingga terkadang menghalalkan segala cara.

Kemudahan untuk memperoleh senjata tajam mampu menjadikan seseorang melakukan tindak kejahatan serta terjadinya kenaikan harga akan barang-barang pokok menjadikan beban keluarga bertambah dan membuat anak menjadi putus sekolah sehingga anggota dalam keluarga dapat terpengaruh untuk menghalalkan segala cara untuk memenuhi kebutuhan, ditambah lagi dengan adanya pengangguran karena sempitnya lapangan pekerjaan yang dapat dikatakan sebagai penyebab timbulnya kejahatan dimana kesemuanya itu di sebabkan oleh faktor ekonomi.

Berdasarkan wawancara terhadap pelaku penyalahgunaan senjata tajam yakni Ahmad Syarkawi Bin Lukman (18 Tahun) mengatakan bahwa melakukan tindak kejahatan karena 


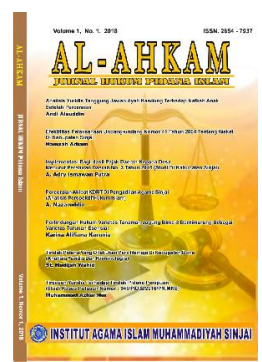

merasa malu dianggap sebagai pengangguran dan putus sekolah. Ahmad Syarkawi Bin Lukman (18 Tahun) menjelaskan bahwa dirinya kerap menjadi bahan perbincangan tetangga karena faktor ekonomi sehingga merasa malu dan nekat mempersiapkan melakukan pembalasan terhadap tetangganya yang kemudian mengajak Darmawan Wahid Bin Abd Wahid (18 Tahun) untuk melakukannya, namun sebelum perbuatan tersebut dilakukan Ahmad Syarkawi Bin Lukman (18 Tahun) dan Darmawan Wahid Bin Abd Wahid (18 Tahun) ditangkap berdasarkan informasi yang diperoleh aparat kepolisian dan ditemukan sebilah badik berukuran panjang $19 \mathrm{~cm}$ dan sebilah samurai berukuran Panjang $49 \mathrm{~cm}$. (hasil wawancara, 20 April 2020).

\subsection{Tindakan yang dilakukan dalam upaya penyelesaian Kasus Penyalahgunaan Senjata Tajam di Kabupaten Sinjai.}

Seiring perkembangan zaman, maka kejahatan dan upaya penyelesaian Kasus Penyalahgunaan Senjata Tajam juga berfariasi yang dilakukan oleh aparat penegak hukum kita. Kejahatan tidak hanya dapat terjadi di perkotaan namun juga kerap kali terjadi di pedesaan, seperti halnya yang terjadi di Kabupaten Sinjai. Gambaran dari upaya penanggulangan kejahatan umumnya bervariasi disesuaikan dengan kebijakan-kebijakan pemerintah dan kultur serta budaya setempat turut mempengaruhi upaya penanggulangan Penyalahgunaan Senjata Tajam di Kabupaten Sinjai.

Dalam upaya penanggulangan kejahatan Penyalahgunaan Senjata Tajam di Kabupaten Sinjai merupakan pekerjaan yang tidak mudah, namun peran orang tua dan masyarakat sekitar maupun aparat kepolisian diharapkan mampu mengupayakan langkah-langkah penanggulangan kejahatan Penyalahgunaan Senjata Tajam di Kabupaten Sinjai.

Untuk menjawab upaya pemerintah setempat dalam menyelesaikan perselisihan yang melibatkan penyalahgunaan Senjata Tajam yang telah menimbulkan korban di kabupaten Sinjai dari tahun 2015 hingga tahun 2019, sebagai berikut :

1. Upaya Preventif

Merupakan suatu upaya pencegahan yang dapat dilakukan secara terencana yang sistematis dan terarah guna mencegah timbulnya Penyalahgunaan Senjata Tajam di kabupaten Sinjai.Dengan mempersempit ruang gerak, mengurangi dan meminimalisir pengaruh terhadap nilai-nilai yang ada didalam masyarakat diharapkan mampu dijadikan sebagai upaya pencegahan. Oleh karena itu diharapkan adanya Kerjasama berbagai pihak, baik itu dari pemerintah maupun dari masyarakat agar dapat berjalan sesuai keinginan Bersama.

Berdasarkan wawancara yang diperoleh terhadap angota Polres Sinjai mengatakan bahwa penanggulangan kejahatan Penyalahgunaan Senjata Tajam yang bersifat Preventif, yaitu :

a. Dikeluarkannya himbauan terhadap masyarakat untuk dapat meningkatkan kesadaran dan kewaspadaan atas segala kemungkinan yang dapat timbul dari Penyalahgunaan Senjata Tajam.

b. Dilakukannya upaya penyuluhan terkait tugas dan tanggung jawab Bersama sehingga tercipta suatu kesadaran hukum di masyarakat sebagai upaya dalam menanggulangi tindak pidana Penyalahgunaan Senjata Tajam di Kabupaten Sinjai.

c. Dilaksanakannya kegiatan patroli dan Razia Bersama terhadap masyarakat yang membawa senjata tajam diluar kegiatan bersawah, berkebun dan beternak.

d. Diberikannya informasi berupa himbauan terhadap masyarakat agar memiliki kesadaran tentang dampak buruk dari seringnya masyarakat membawa senjata tajam dan memberikan informasi kepada aparat setempat bila ditemukannya halhal yang dicurigai berkaitan dengan Penyalahgunaan Senjata Tajam. 


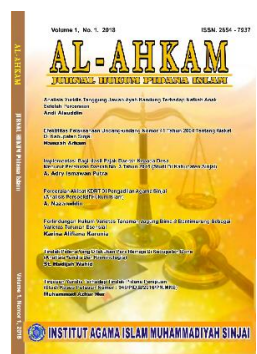

e. Diberlakuannya pembatasan jam malam di daerah yang rawan terjadi pertikaian menggunakan senjata tajam.

f. Dibentuknya program-program pendukung seperti PKK dan LKMD dengan memberikan penyuluhan kepada masyarakat akan pentingnya menjaga hubungan baik dalam keluarga maupun dimasyarakat, membina mental dan memperdalam agama serta menanamkan kedisiplinan agar tidak membawa atau menggunakan senjata tajam dalam setiap situasi dan memberikan pemahaman serta pengetahuan akan akibat hukum yang akan diterima jika melakukan Penyalahgunaan Senjata Tajam.

2. Upaya Represif

Adapun upaya lain yang ditempuh yaitu upaya represif atau upaya penindakan terhadap kasus-kasus Penyalahgunaan Senjata Tajam. Dalam upaya penanggulangan kejahatan Penyalahgunaan Senjata Tajam diabupaten sinjai, kesatuan Polres Sinjai melakukan tindakan sebagai berikut :

a. Pembentukan tim yang bertugas di daerah-daerah rawan terjadi pertikaian dengan membaur di masyarakat sehingga mampu mendeteksi sejak dini konflik yang ada dimasyarakat sehinggap dapat menangkap oknum yang terbukti hendak melakukan kejahatan Penyalahgunaan Senjata Tajam

b. Penangkapan terhadap pelaku Penyalahgunaan Senjata Tajam berdasarkan laporan korban atau keluarga korban.

c. Pemeriksaan terkait laporan yang telah diajukan terhadap tersangka dan barang bukti serta upaya lainnya yang berkaitan dengan proses penyidikan yang kemudian dilakukan pelimpahan ke Kejaksaan.

Dari uraian upaya-upaya yang telah dilakukan oleh aparat kepolisian dalam menanggulangi masalah kejahatan khususnya kejahatan Penyalahgunaan Senjata Tajam dikabupaten Sinjai, jalur Pendidikan dan agama dianggap efisien untuk peningkatan pengetahuan untuk mulai meninggalkan kebiasaan membawa dan menyelesaikan perselisihan menggunakan senjata tajam dianggap cukup mampu mengatasi permasalahan yang ada.

Penanggulangan kejahatan khususnya kejahatan Penyalahgunaan Senjata Tajam di harapkan dilakukan penghukuman yaitu sistem pemidanaan yang bertujuan memberikan efek jera terhadap pelaku sehingga upaya ini mampu membina dam memperbaiki mental masyarakat di Kabupaten Sinjai serta mampu meninggalkan budaya lama yang telah ditanamkan oleh pendahulu mereka sehingga menjadi generasi penerus yang dapat hidup berdampingan dengan suku bangsa yang lain serta menghilangkan niat buruk para pelaku kejahatan Penyalahgunaan Senjata Tajam untuk Kembali mengulangi perbuatannya mengingat hukuman berat yang akan diberikan bila mengulangi perbuatannya.

\section{Simpulan}

Dalam penelitian tersebut diatas dapat ditarik suatu kesimpulan bahwa kejahatan Penyalahgunaan Senjata Tajam di Kabupaten Sinjai dari tahun 2015 hingga tahun 2019 sebagai berikut :

1. Faktor penyebab terjadinya delik Penyalahgunaan Senjata Tajam di Kabupaten Sinjai dari tahun 2015 hingga tahun 2019 yaitu faktor Lingkungan Keluarga yaitu senjata tajam dianggap sebagai alat untuk mejaga atau untuk membela diri, Faktor Pergaulan yaitu sikap dan sifat jahat seseorang dapat dipengaruhi oleh sikap dan sifat jahat individu lainnya dan faktor Ekonomi yaitu adanya rasa malu dianggap sebagai pengangguran dan putus sekolah sehingga nekat mempersiapkan diri dalam melakukan suatu tindakan menggunakan senjata tajam. 


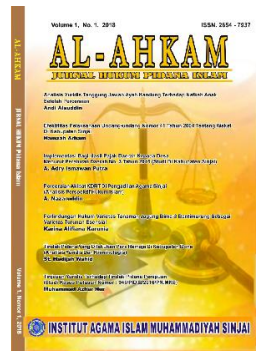

2. Kejahatan penyalahgunaan Senjata Tajam di Kabupaten Sinjai dalam kurun waktu 5 (lima) tahun terakhir terus mengalami penurunan. Aparat kepolisian Kabupaten Sinjai melakukan penanggulangan kejahatan Penyalahgunaan Senjata Tajam menggunakan upaya pencegahan dan penindakan yang mampu menanggulangi masalah kejahatan khususnya kejahatan Penyalahgunaan Senjata Tajam dikabupaten Sinjai.

\section{Daftar Pustaka}

Upe Ambo. (2010). Tradisi Aliran dalam Sosiologi. Jakarta, PT. Raja Grafindo Persada.

Sudarto. (1981). Hukum dan Hukum Pidana. Alumni. Bandung.

Andi Hamzah. (1986). Sistem Pidana dan Pemidanaan Indonesia. dari Retribusi ke Reformasi. Pradnya Paramita. Jakarta

\section{Jurnal Cetak:}

Tamrin. (2014). Kesantunan Berbahasa Bugis Pada Masyarakat Bugis Di Kabupaten Sinjai Provinsi Sulawesi Selatan. Balai Bahasa Provinsi Sulawesi Tengah. Multilingual Volume XIII No. 2 Tahun 2014. P209.

Ruwaidah. (2018). Makna Badik Bagi Masyarakat Suku Bugis. Fakultas Ilmu Sosial dan Ilmu Politik Universitas Riau. JOM FISIP Vol. 5 No. 1 April 2018. P3

\section{Dokumen dari internet:}

Diakses dari https://sahabatkeluarga.kemendikbud.go.id/m/index.php?r=populer/xview\&id=4681.

\section{Undang-Undang}

Undang-Undang Darurat No.12 Tahun 1951 tentang mengubah "Ordonnantietijdelijke Bijzondere Strafbepalingen" 